\title{
Specificity of ${ }^{15} \mathrm{~N}$ NMR chemical shifts to the nature of substituents and tautomerism in substituted pyridine $N$-oxides
}

\author{
Aniela Puszko $\cdot$ Katri Laihia $\cdot$ Erkki Kolehmainen • \\ Zofia Talik
}

Received: 6 February 2012/ Accepted: 15 May 2012/Published online: 26 June 2012

(c) The Author(s) 2012. This article is published with open access at Springerlink.com

\begin{abstract}
H},{ }^{13} \mathrm{C}$, and ${ }^{15} \mathrm{~N}$ NMR chemical shifts have been measured for 2-aminopyridine $N$-oxide (1), its eleven derivatives $(\mathbf{2}-\mathbf{1 0}, \mathbf{1 3}, \mathbf{1 4})$, and $3-\mathrm{Cl}$ and $3-\mathrm{Br}$ substituted 4-nitropyridine $N$-oxides $(\mathbf{1 1}, \mathbf{1 2}) . \delta\left({ }^{15} \mathrm{~N}\right)$ of pyridine ring nitrogen in 2-acetylaminopyridine $N$-oxides are $5.9-11.5 \mathrm{ppm}$ deshielded from those in 2 -aminopyridine $N$-oxides. When amino and acetylamino substituents are in 4-position, $\delta\left({ }^{15} \mathrm{~N}\right)$ of ring nitrogen is $21.3 \mathrm{ppm}$ deshielded in the acetylated derivative. The strong resonance interaction between 2-amino and 5-nitro groups reflects in the decrease of amino nitrogen shielding about 5.3-17.9 ppm. Also, ${ }^{1} \mathrm{H}$ and ${ }^{13} \mathrm{C}$ NMR spectral data are in agreement with ${ }^{15} \mathrm{~N}$ NMR results reflected as deshielded amino protons and carbons C-2 and C-5. The pyridine nitrogen chemical shift in all amino- and acetylamino derivatives vary between -101.2 and $-126.7 \mathrm{ppm}$, which has been connected with the tautomeric balance in our earlier studies.
\end{abstract}

Keywords ${ }^{1} \mathrm{H} \cdot{ }^{13} \mathrm{C} \cdot{ }^{15} \mathrm{~N} \cdot \mathrm{NMR} \cdot 2$-Aminopyridine $\mathrm{N}$-oxide $\cdot 2$-Amino-5-nitropyridine $\mathrm{N}$-oxide .

2-Acetylaminopyridine $N$-oxide $\cdot 4$-Aminopyridine $\mathrm{N}$-oxide $\cdot 4$-Acetylaminopyridine $\mathrm{N}$-oxide

Z. Talik: Deceased.

A. Puszko $(\square) \cdot$ Z. Talik

Department of Bioorganic Chemistry, Faculty of Industry and Economics, University of Economics, 53-345 Wrocław, Poland

K. Laihia · E. Kolehmainen

Department of Chemistry, University of Jyväskylä,

FI-40014 Jyväskylä, Finland

\section{Introduction}

${ }^{15} \mathrm{~N}$ isotope is the most sensitive NMR nucleus to the effect of a substituent introduced to pyridine $\mathrm{N}$-oxide (2- and 4-amino, 2- and 4-acetylamino, methyl group in different positions together with 2-amino and/or 2-acetylamino, 5-nitro with 2-amino, 4-nitro together with 3-chloro and 3-bromo e.g.). Pyridine $\mathrm{N}$-oxides possess an $\mathrm{N}-\mathrm{O}$-moiety, a dual resonance functionality, that can act as both a $\pi$-electron donor and a $\pi$-electron acceptor [1]. Acceptors in the ring decrease and donors increase the shielding of ${ }^{15} \mathrm{~N}$. A linear relationship has been observed between the substituent chemical shifts of ${ }^{15} \mathrm{~N}$ and ${ }^{13} \mathrm{C}$ for the related substituted benzenes.

Only few research reports on ${ }^{15} \mathrm{~N}$ and ${ }^{14} \mathrm{~N}$ NMR studies of aminopyridine $N$-oxides are found in the literature [2-5]. In this paper, we present our studies regarding the possible tautomerism in amino and acetylaminopyridine $N$-oxides because this problem has not yet been unambiguously solved. Another interest lies in the 5-nitro-substituted compounds $(10,13,14)$, where the electron lone pair of amino moiety is involved in the $\pi$-electron conjugation with the aromatic ring the nitro group acting as an electron acceptor.

Recently, 2-amino-5-nitropyridine derivatives have been shown to be very interesting owing to their promising nonlinear optical properties as these molecules possess high hyperpolarizability and highly delocalised $\pi$-electron system for reason that acceptor and donor group are situated in para-position to each other [6].

\section{Experimental}

2-Aminopyridine $\mathrm{N}$-oxide and its 3 - and 5-methyl derivatives were obtained by protecting the primary amino group 
by acetylation during the oxidation of ring nitrogen. Otherwise, oxidation would have transformed aminopyridines into nitropyridines [7-15]. In hydrolysis, acetylamino derivatives of pyridine $\mathrm{N}$-oxide gave the corresponding amino compounds [7]. 2-Amino- and 2-acetylaminopyridine $\mathrm{N}$-oxides as well as their 3-, 4-, 5-, and 6-methyl derivatives are reported in literature $[8,9]$, but their synthesis were greatly improved [14] compared to the earlier reported methods [8-13].

\section{Synthesis}

The modified synthesis of 2-acetylaminopyridine $\mathrm{N}$-oxides $(2,4)$ and 4-, 5-, and 6-methyl-(2-acetylaminopyridine- $N$ oxides) $(\mathbf{7}, \mathbf{8}, 9)[8-10,13]$ has been presented previously [14]. By modification of methods by Brown and Adam et al. $[9,10]$, a remarkable shortening in reaction time (9 to $2 \mathrm{~h}$ ) was achieved by substituting acetic acid by acetic anhydride in the reaction.

The syntheses of 2-amino- (1), 4-amino- (3), 2-amino-3methyl- (5), 2-amino-5-methylpyridine $N$-oxide (6) have also been reported earlier [16]. These compounds were obtained by hydrolysis of the corresponding acetylaminopyridine $N$-oxides [13]. By Herz's hydrolysis method [13] with $50 \% \mathrm{H}_{2} \mathrm{SO}_{4}$ instead of $10 \% \mathrm{NaOH}$ decreases, the reaction time varied from 5 to $1 \mathrm{~h}[9,10]$.

The syntheses of 2-amino-5-nitro- (10), 2-amino-5nitro-3-methyl- (13) and 2-amino-5-nitro-6-methylpyridine $N$-oxides (14) have been presented previously [16, 17]. These compounds were obtained in rearrangement reaction of the corresponding nitraminopyridine $N$-oxides [16, 17].

3-Chloro- (11) and 3-bromo-4-nitropyridine $N$-oxides (12) were prepared by oxidation of 3-chloro- and 3-bromopyridine by $30 \% \quad \mathrm{H}_{2} \mathrm{O}_{2}$ in the presence of acetic anhydride followed by nitration of the crude products after the excess acid was removed [18]. The modification of this synthesis in comparison with earlier applied methods [7] consists an improvement of $\mathrm{N}$-oxidation (using acetic anhydride instead of acetic acid) and separation of final product from reaction mixture (using $25 \% \mathrm{NH}_{4} \mathrm{OH}$ and $\mathrm{NH}_{4} \mathrm{HCO}_{3}$ instead of $\mathrm{NaOH}$ ) giving the pure product due to low temperature during the neutralization process.

\section{NMR spectroscopy}

The ${ }^{1} \mathrm{H},{ }^{13} \mathrm{C}$ and PFG $[19]{ }^{1} \mathrm{H},{ }^{13} \mathrm{C}$ HMQC [20, 21], and PFG ${ }^{1} \mathrm{H}, X\left(X={ }^{13} \mathrm{C}\right.$ or $\left.{ }^{15} \mathrm{~N}\right)$ HMBC [22] spectra were recorded for $0.5 \mathrm{M}$ DMSO- $\mathrm{d}_{6}$ solution in a $5-\mathrm{mm}$ sample tube at $30{ }^{\circ} \mathrm{C}$ on a Bruker Avance DRX 500 spectrometer working at $500.13 \mathrm{MHz}$ (proton), $125.77 \mathrm{MHz}$ (carbon-13) and $50.70 \mathrm{MHz}$ (nitrogen-15), respectively.

In ${ }^{1} \mathrm{H}$ NMR experiments, the number of data points was $64 \mathrm{~K}$ giving a spectral resolution of $0.05 \mathrm{~Hz}$, the number of scans was 8 and the flip angle $30^{\circ}$. An exponential window function of the spectral resolution was used before FT. The ${ }^{1} \mathrm{H}$ NMR chemical shifts are referenced to the signal of residual DMSO- $\mathrm{d}_{5}(\delta=2.50 \mathrm{ppm}$ from TMS $)$.

In ${ }^{13} \mathrm{C}$ experiments, the number of data points was $32 \mathrm{~K}$ giving a spectral resolution of $0.5 \mathrm{~Hz}$, the number of scans was 64 , and flip angle $30^{\circ}$. A composite pulse decoupling, Waltz16 , was used to remove proton couplings. An exponential window function of the spectral resolution was used before FT. The ${ }^{13} \mathrm{C}$ NMR chemical shifts are referenced to the center peak of the solvent DMSO- $\mathrm{d}_{6}(\delta=39.50 \mathrm{ppm}$ from TMS). The number of data points in $\mathrm{PFG}{ }^{1} \mathrm{H},{ }^{13} \mathrm{C}$ HMQC, and $\mathrm{HMBC}$ measurements were $1,024\left(f_{2}\right) \times 256\left(f_{1}\right)$. This matrix was zero filled to $2,048 \times 1,024$ and apodized by a shifted sine bell window function along both axes before FT.

In PFG ${ }^{1} \mathrm{H},{ }^{15} \mathrm{~N}$ HMBC experiments, the digital resolution was $<0.5 \mathrm{ppm}$ and a 50 -ms delay was used for the evolution of long-range couplings. The number of data points were $1,024\left(f_{2}\right) \times 512 / 450 \mathrm{ppm}\left(f_{1}={ }^{15} \mathrm{~N}\right)$. This matrix was zero filled to $1,024 \times 1,024$ and apodized by a shifted sine bell window function along both axes before FT. ${ }^{15} \mathrm{~N}$ NMR chemical shifts are referenced to the signal of an external $\mathrm{CH}_{3} \mathrm{NO}_{2}(\delta=0.0 \mathrm{ppm})$.

\section{Results and discussion}

The structures of compounds 1-14 are presented in Fig. 1. The ${ }^{1} \mathrm{H},{ }^{13} \mathrm{C}$, and ${ }^{15} \mathrm{~N}$ NMR chemical shifts are collected in Tables 1, 2, and 3 .

Regarding ${ }^{15} \mathrm{~N}$ NMR shifts, we can use our previous papers for comparison [6, 23, 24].

\section{${ }^{1} \mathrm{H}$ NMR shifts}

The ${ }^{1} \mathrm{H}$ NMR data reveal the electron acceptor ability of the acetyl group via $\delta(\mathrm{H}-3)$ (ortho to acetylamino). In $2, \delta(\mathrm{H}-3)$ is $1.49 \mathrm{ppm}$ and in 7-9 $1.34-1.38 \mathrm{ppm}$ deshielded in comparison with 1 showing the strong electron withdrawing property of acetylamino group. In 4-acetylamino substituted derivative, $\delta(\mathrm{H}-3 / 5)$ are just $1.08 \mathrm{ppm}$ deshielded from that of 4-amino derivative (3). In 5-nitro derivatives, the greatest deshieldings, 0.89 and 0.88 ppm for $\mathrm{H}-6$ and $\mathrm{H}-4$, respectively (10), $0.82 \mathrm{ppm}$ for both protons (13) and $0.79 \mathrm{ppm}$ for H-4 (14), are observed. Joint with these effects, one can observe deshieldings of amino protons by $1.31 \mathrm{ppm}(\mathbf{1 0})$, $1.20 \mathrm{ppm}(\mathbf{1 3})$, and $1.16 \mathrm{ppm}(\mathbf{1 4})$ which refer to resonance interaction between amino and nitro group.

\section{${ }^{13} \mathrm{C}$ NMR shifts}

The assignments of ${ }^{13} \mathrm{C}$ NMR chemical shifts (Table 2) are based on literature data and substituent induced chemical 
<smiles>[R]c1c([R])c([R])[n+]([O-])c([R])c1[R]</smiles>

$\begin{array}{llllll}\text { Compound } & \mathrm{R}_{1} & \mathrm{R}_{2} & \mathrm{R}_{3} & \mathrm{R}_{4} & \mathrm{R} \\ \text { 1. } & \mathrm{NH}_{2} & \mathrm{H} & \mathrm{H} & \mathrm{H} & \mathrm{H} \\ \text { 2. } & \mathrm{NHCOCH}_{3} & \mathrm{H} & \mathrm{H} & \mathrm{H} & \mathrm{H} \\ \text { 3. } & \mathrm{H} & \mathrm{H} & \mathrm{NH}_{2} & \mathrm{H} & \mathrm{H} \\ \text { 4. } & \mathrm{H} & \mathrm{H} & \mathrm{NHCOCH}_{3} & \mathrm{H} & \mathrm{H} \\ \text { 5. } & \mathrm{NH}_{2} & \mathrm{CH}_{3} & \mathrm{H} & \mathrm{H} & \mathrm{H} \\ \text { 6. } & \mathrm{NH}_{2} & \mathrm{H} & \mathrm{H} & \mathrm{CH}_{3} & \mathrm{H} \\ \text { 7. } & \mathrm{NHCOCH}_{3} & \mathrm{H} & \mathrm{CH} & \mathrm{H} & \mathrm{H} \\ \text { 8. } & \mathrm{NHCOCH}_{3} & \mathrm{H} & \mathrm{H} & \mathrm{CH}_{3} & \mathrm{H} \\ \text { 9. } & \mathrm{NHCOCH}_{3} & \mathrm{H} & \mathrm{H} & \mathrm{H} & \mathrm{CH} \\ \text { 10. } & \mathrm{NH}_{2} & \mathrm{H} & \mathrm{H} & \mathrm{NO}_{2} & \mathrm{H} \\ \text { 11. } & \mathrm{H} & \mathrm{Cl} & \mathrm{NO}_{2} & \mathrm{H} & \mathrm{H} \\ \text { 12. } & \mathrm{H} & \mathrm{Br} & \mathrm{NO}_{2} & \mathrm{H} & \mathrm{H} \\ \text { 13. } & \mathrm{NH}_{2} & \mathrm{CH} & \mathrm{H} & \mathrm{NO}_{2} & \mathrm{H} \\ \text { 14. } & \mathrm{NH}_{2} & \mathrm{H} & \mathrm{H} & \mathrm{NO}_{2} & \mathrm{CH} \\ & & & & & \\ & & & & & \end{array}$

Fig. 1 Structures of 1-14

shifts [6, 23-25] as well as homo- and heteronuclear 2D chemical shift correlation measurements. When C-2 in pyridine $\mathrm{N}$-oxide is substituted with an amino group the ipso carbon chemical shift changes from $138.2 \mathrm{ppm}$ [25] to
150.69 ppm (1). In its methylated derivatives (5) and (6), the 2-ipso carbon is 1.11 (5) and $2.18 \mathrm{ppm}$ (6) shielded from that of $\mathbf{1}$. The substitution of hydrogen in amino group by acetyl group (2) increases the shielding in ipso carbon $\mathrm{C}-2 \mathrm{ppm}$ by $6.97 \mathrm{ppm}$ and in the methylated derivatives by ca. 4-9 ppm (7, 8, and 9). When the methyl group locates at C-5 (8), the deshielding of C-5 is $17.0 \mathrm{ppm}$ due to hyperconjugation with the methyl group. When a 5-nitro group is introduced into 2-amino-pyridine $N$-oxide (10) and its 3- (13) and 6-methyl (14) derivatives, the increase in $\delta(\mathrm{C}-2)$ is $3.0-4.4 \mathrm{ppm}$ and in $\delta(\mathrm{C}-5) 21-23 \mathrm{ppm}$. Again these changes are due to resonance interaction between the 2-amino and 5-nitro group.

${ }^{15} \mathrm{~N}$ NMR shifts

Our earlier studies on pyridine $\mathrm{N}$-oxides show that in nitraminopyridine and $\mathrm{N}$-alkylamino-4-nitro derivatives possessing a tertiary amino group at $\mathrm{C}-2, \delta\left({ }^{15} \mathrm{~N}\right)$ of the ring nitrogen varies from -92.7 to $-93.0 \mathrm{ppm}$. It means that these compounds exist mainly as amino tautomers $[6,23$, 24]. In neat pyridine $N$-oxide, the corresponding $\delta\left({ }^{15} \mathrm{~N}\right)$ is $-86.8 \mathrm{ppm}$ [25]. Also, in a compound with a secondary amino substituent at $\mathrm{C}-3 \delta\left({ }^{15} \mathrm{~N}\right)$ is -86.9 ppm revealing its tautomeric preference as an amino form. In 3-methyl-2nitraminopyridine $\mathrm{N}$-oxide, the corresponding value of $\delta\left({ }^{15} \mathrm{~N}\right)$ is $-94.4 \mathrm{ppm}$. The predominance of the amino tautomer is in agreement with quantum chemical ab initio HF/6-311G** structure optimization and energy calculations [6]. The greater stability of the amino tautomer can be explained that while the $\mathrm{N}-\mathrm{NO}_{2}$ group is twisted to one side of the plane of the aromatic ring the spatial vicinity of two substituents inhibit the conjugation between the

Table $1{ }^{1} \mathrm{H}$ NMR chemical shifts of $\mathbf{1 - 1 4}$ (ppm from int. TMS) in $0.5 \mathrm{M} \mathrm{DMSO}-\mathrm{d}_{6}$ at $30{ }^{\circ} \mathrm{C}$

\begin{tabular}{|c|c|c|c|c|c|c|c|c|c|}
\hline \multirow[t]{2}{*}{ Compound } & \multicolumn{9}{|c|}{$\delta\left({ }^{1} \mathrm{H}\right)$} \\
\hline & $\mathrm{H}-2$ & $\mathrm{H}-3$ & $\mathrm{H}-4$ & H-5 & H-6 & $\mathrm{CH}_{3}$ & $\mathrm{COCH}_{3}$ & $\mathrm{NH}_{2}$ & $\mathrm{NHCOCH}_{3}$ \\
\hline 1 & - & 6.78 & 7.09 & 6.56 & 8.02 & - & - & 6.82 & - \\
\hline 2 & - & 8.27 & 7.38 & 7.11 & 8.35 & - & 2.26 & - & 10.49 \\
\hline 3 & 7.77 & 6.52 & - & 6.52 & 7.77 & - & - & 6.30 & - \\
\hline 4 & 8.10 & 7.60 & - & 7.60 & 8.10 & - & 2.07 & - & 10.99 \\
\hline 5 & - & - & 6.99 & 6.52 & 7.91 & 2.15 & - & 6.65 & - \\
\hline 6 & - & 6.72 & 6.95 & - & 7.88 & 2.10 & - & 6.53 & - \\
\hline 7 & - & 8.12 & - & 6.94 & 8.21 & 2.30 & 2.25 & - & 10.41 \\
\hline 8 & - & 8.15 & 7.22 & - & 8.25 & 2.23 & 2.21 & - & 10.39 \\
\hline 9 & - & 8.16 & 7.28 & 7.16 & - & 2.42 & 2.25 & - & 10.52 \\
\hline 10 & - & 6.87 & 7.97 & - & 8.91 & - & - & 8.13 & - \\
\hline 11 & 8.80 & - & - & 8.21 & 8.37 & - & - & - & - \\
\hline 12 & 8.86 & - & - & 8.18 & 8.39 & - & - & - & - \\
\hline 13 & - & - & 7.91 & - & 8.84 & 2.25 & - & 8.02 & - \\
\hline 14 & - & 6.79 & 7.88 & - & - & 2.74 & - & 7.98 & - \\
\hline
\end{tabular}


Table $2{ }^{13} \mathrm{C}$ NMR chemical shifts of $\mathbf{1 - 1 4}$ (ppm from int. TMS) in $0.5 \mathrm{M} \mathrm{DMSO}-\mathrm{d}_{6}$ at $30{ }^{\circ} \mathrm{C}$

\begin{tabular}{|c|c|c|c|c|c|c|c|c|}
\hline \multirow[t]{2}{*}{ Compound } & \multicolumn{8}{|l|}{$\delta\left({ }^{13} \mathrm{C}\right)$} \\
\hline & $\mathrm{C}-2$ & $\mathrm{C}-3$ & C-4 & C-5 & C-6 & $\mathrm{CH}_{3}$ & $\mathrm{COCH}_{3}$ & $\mathrm{CO}$ \\
\hline 1 & 150.69 & 109.00 & 126.83 & 112.05 & 136.96 & - & - & - \\
\hline 2 & 143.72 & 114.58 & 126.86 & 119.12 & 137.37 & - & 24.24 & 169.57 \\
\hline 3 & 138.55 & 110.12 & 147.91 & 110.12 & 138.55 & - & - & - \\
\hline 4 & 138.84 & 115.72 & 150.27 & 115.72 & 138.84 & - & 23.96 & 169.14 \\
\hline 5 & 149.58 & 118.08 & 127.18 & 111.30 & 134.42 & 16.65 & - & - \\
\hline 6 & 148.51 & 108.76 & 128.05 & 121.43 & 136.23 & 16.67 & - & - \\
\hline 7 & 142.88 & 114.67 & 137.85 & 119.81 & 136.47 & 20.29 & 24.27 & 169.48 \\
\hline 8 & 141.41 & 114.11 & 127.79 & 129.01 & 136.83 & 17.02 & 24.15 & 169.30 \\
\hline 9 & 146.53 & 111.77 & 125.63 & 119.19 & 143.55 & 17.54 & 24.32 & 169.41 \\
\hline 10 & 155.04 & 106.30 & 123.01 & 133.89 & 133.79 & - & - & - \\
\hline 11 & 140.57 & 126.22 & 141.19 & 122.86 & 139.04 & - & - & - \\
\hline 12 & 142.66 & 113.93 & 143.11 & 122.71 & 139.16 & - & - & - \\
\hline 13 & 154.22 & 116.34 & 122.72 & 133.11 & 131.53 & 16.71 & - & - \\
\hline 14 & 153.66 & 103.56 & 123.66 & 135.33 & 145.56 & 14.92 & - & - \\
\hline
\end{tabular}

Table $3{ }^{15} \mathrm{~N}$ NMR shifts (ppm from ext. $\mathrm{CH}_{3} \mathrm{NO}_{2}$ ) of $\mathbf{1}-\mathbf{1 4}$ in $0.5 \mathrm{M}$ $\mathrm{DMSO}^{\mathrm{d}} \mathrm{d}_{6}$ at $30{ }^{\circ} \mathrm{C}$

\begin{tabular}{lcccc}
\hline Compound & \multicolumn{2}{c}{$\delta\left({ }^{15} \mathrm{~N}\right)$} & & \\
\cline { 2 - 5 } & $\mathrm{Ring}$ & $\mathrm{NH}_{2}$ & $\mathrm{NO}_{2}$ & $\mathrm{NHCOCH}_{3}$ \\
\hline $\mathbf{1}$ & 126.1 & 315.8 & - & - \\
$\mathbf{2}$ & 114.6 & - & - & 254.5 \\
$\mathbf{3}$ & 122.5 & 310.8 & - & - \\
$\mathbf{4}$ & 101.2 & - & - & 246.7 \\
$\mathbf{5}$ & 126.7 & 317.1 & - & - \\
$\mathbf{6}$ & 126.0 & 318.9 & - & - \\
$\mathbf{7}$ & 120.1 & - & - & 254.4 \\
$\mathbf{8}$ & 114.6 & - & - & 255.2 \\
$\mathbf{9}$ & 116.1 & - & - & 254.2 \\
$\mathbf{1 0}$ & 126.5 & 298.1 & 16.7 & - \\
$\mathbf{1 1}$ & 74.7 & - & 19.2 & - \\
$\mathbf{1 3}$ & - & 297.9 & 16.9 & - \\
$\mathbf{1 4}$ & 122.9 & 310.5 & - & - \\
\hline
\end{tabular}

2-nitramino and pyridine ring increasing the energy of the amino form, which, however, is slightly more stable than the imino form. When the molar ratio of the imino form in the tautomer balance is increasing, the $\delta\left({ }^{15} \mathrm{~N}\right)$ of ring nitrogen becomes more shielded varying from -124.1 to -168.7. In 4-nitro derivatives with secondary 2-amino substituent, $\delta\left({ }^{15} \mathrm{~N}\right)$ of ring varies from -112.8 to $-120.9 \mathrm{ppm}$ [22] and in 5-nitro derivatives with secondary 2-amino substituent from -128.4 to $-129.5[24] . \delta\left({ }^{15} \mathrm{~N}\right)$ of ring in pyridine $N$-oxide and 2-aminopyridine $N$-oxide are $-86.6 \mathrm{ppm}[6]$ and $-126.1 \mathrm{ppm}$, respectively. In all other derivatives, the aromatic nitrogen chemical shifts from 114.6 to 126.7 ppm mean that the molar ratio of the imino form in the tautomer balance is increasing.

In 2-aminopyridine $N$-oxide $(\mathbf{1}), \delta\left({ }^{15} \mathrm{~N}\right)$ of amino is $-315.8 \mathrm{ppm}$. Introduction of methyl group to 2-aminopyridine to $\mathrm{C}-3$ (5) or to $\mathrm{C}-5$ (6) has a minimal effect on the amino shift differing from that of 5-nitro group (10), i.e., $17.7 \mathrm{ppm}$. The $p$-nitro group together with 3-and 6-methyl substituents $(\mathbf{1 3}, \mathbf{1 4})$ decreases the amino nitrogen shift 17.9 and $5.3 \mathrm{ppm}$, respectively.

In conclusion, taking into account the large chemical shift range and sensitivity to substituents of ${ }^{15} \mathrm{~N}$, we can state that there are characteristic $\delta\left({ }^{15} \mathrm{~N}\right)$ ranges for pyridine- $N$ oxides possessing $\mathrm{NH}_{2}, \mathrm{NHCOCH}_{3}$, and $\mathrm{NO}_{2}$ substituents. $\delta\left({ }^{15} \mathrm{~N}\right)$ of ring vary from -74.7 to $-126.7 \mathrm{ppm}$, $\delta\left({ }^{15} \mathrm{~N}\right)$ of primary amino from -297.9 to $-318.9 \mathrm{ppm}$, $\delta\left({ }^{15} \mathrm{~N}\right)$ of amino in acetyl derivatives from -246.7 to $-255.2 \mathrm{ppm}$, and $\delta\left({ }^{15} \mathrm{~N}\right)$ of nitro group from -16.7 to $-19.2 \mathrm{ppm} . \delta\left({ }^{15} \mathrm{~N}\right)$ of ring is somewhat sensitive to the nature of substituent at $\mathrm{C}-2$. When the $\mathrm{NH}_{2}$ is substituted by $\mathrm{NHCOCH}_{3}, \delta\left({ }^{15} \mathrm{~N}\right)$ of ring becomes slightly deshielded, while the deshielding in amino nitrogen is larger being 61-69 ppm. As a whole, the ${ }^{15} \mathrm{~N}$ NMR shifts manifest a strong resonance interaction between 2-amino and 5-nitro groups by 17.7 ppm (10), 19.9 ppm (13), and 5.3 ppm (14) deshielding in $\delta\left({ }^{15} \mathrm{~N}\right)$ of the amino group.

\section{Conclusions}

Among NMR parameters for fifteen substituted pyridine $\mathrm{N}$-oxides reported in this study, ${ }^{15} \mathrm{~N}$ NMR chemical shifts 
are the most sensitive to the effects of substituent and tautomerism.

$\delta\left({ }^{15} \mathrm{~N}\right)$ of the pyridine ring nitrogen in 2-acetylaminopyridine $N$-oxides are 5.9-11.5 ppm deshielded from those in 2-aminopyridine $\mathrm{N}$-oxides. When amino and acetylamino substituents are in 4-position, $\delta\left({ }^{15} \mathrm{~N}\right)$ of ring nitrogen is $21.3 \mathrm{ppm}$ deshielded in the acetylated derivative. The strong resonance interaction between 2-amino and 5-nitro groups reflects in the decrease of amino nitrogen shielding about 5.3-17.9 ppm. The pyridine nitrogen chemical shift in all amino- and acetylamino derivatives vary between -101.2 and $-126.7 \mathrm{ppm}$, which has been connected with the tautomeric balance in our earlier studies. Also, ${ }^{1} \mathrm{H}$ and ${ }^{13} \mathrm{C}$ NMR spectral data are in agreement with ${ }^{15} \mathrm{~N}$ NMR results.

Open Access This article is distributed under the terms of the Creative Commons Attribution License which permits any use, distribution, and reproduction in any medium, provided the original author(s) and the source are credited.

\section{References}

1. Sawada M, Takai Y, Yamano S, Misumi S, Hanafusa T, Tsuno Y (1988) J Org Chem 53:191

2. Stefaniak L (1976) Spectrochim Acta 32A:345

3. Stefaniak L, Witanowski M, Webb GA (1983) Bull Acad Pol Sci Ser Sci Chim 29:489 and references cited therein
4. Paudler WW, Jovanovic M (1982) Heterocycles 19:93

5. Crabtree KN, Hostetler KJ, Munsch TE, Neuhaus P, Lahti PM, Sander W, Poole JS (2008) J Org Chem 73:3441

6. Laihia K, Kolehmainen E, Virtanen E, Nissinen M, Puszko A, Talik Z (2003) Magn Reson Chem 41:721

7. Abramovitch RA, Smith EM (1974) In: Abramovitch RA (ed) Pyridine and its derivatives, vol 2. Interscience, New York, p 96 and references cited therein

8. Bernstein J, Losee K, Lott WA (1950) J Am Chem Soc 72:4362

9. Brown EV (1957) J Am Chem Soc 79:3565

10. Adam M, Miyano S (1954) J Am Chem Soc 76:2785

11. Taylor EC, Driscoll JS (1960) J Org Chem 25:1716

12. Taylor EC, Driscoll JS (1961) J Org Chem 26:3001

13. Herz W, Murty DKR (1960) J Org Chem 25:2242

14. Talik Z, Talik T, Ban-Oganowska H, Puszko A (1982) Prace Naukowe AE 191:97

15. Dehn JW, Salina AJ (1966) Patent USA 3249 597. Chem Abstr 65(90):61b

16. Talik T, Talik Z (1982) Prace Naukowe AE 199:145

17. Talik T, Talik Z (1987) Prace Naukowe AE 397:141

18. Talik T, Talik Z (1962) Roczniki Chemii 36:539

19. Hurd RE, John BK (1991) J Magn Reson 91:648

20. Bax A, Griffey RH, Hawkins BL (1983) J Magn Reson 55:301

21. Bax A, Subramanian S (1986) J Magn Reson 67:565

22. Bax A, Summers MF (1986) J Am Chem Soc 108:2093

23. Laihia K, Puszko A, Linnanto J, Kolehmainen E (2006) J Mol Struct 783:73

24. Laihia K, Kolehmainen E, Kauppinen R, Lorenc J, Puszko A (2002) Spectrochim Acta A 58:1425

25. Laihia K, Puszko A, Kolehmainen E, Lorenc J (2008) J Mol Struct 889:371 